DOI: $10.2478 / \mathrm{v} 10025-010-0025-6$

\title{
Estimation and economic valuation of the forest retention capacities
}

\author{
Jan TYSZKA
}

Forest Research Institute in Sękocin Stary, Forest Site Science Department, Braci Leśnej 3, 05-090 Raszyn, Poland; j.tyszka@ibles.waw.pl

\begin{abstract}
Based on results concerning the forest impact on water cycling an attempt was undertaken to evaluate water retention in forests. The economic value of water retention was established assuming the cost of water storage in small reservoirs built in forest areas. Calculations did not account for differences resulting from different functions of naturally retained water and that stored with the use of technical methods. Considering volume and time of water retention in forests, the annual value of natural water retention in forests calculated per average hectare of the country area was estimated at $800 \mathrm{zl}$.
\end{abstract}

Key words: economic valuation, forest, water retention

\section{INTRODUCTION}

Management of water resources in forests requires knowledge of economic effectiveness of water management which has been pointed out in Warsaw Declaration of the EU „Forests and water”. In this aspect it is important to estimate the value of water retained in forests as an element of a wider issue of the valuation of various forest functions. Hardly interpretable evaluation of non-productive forest functions is usually based on theoretical background and often on indicatory data estimated in subjective way. An attempt was undertaken to calculate the economic value of water retention capacity in forests by interpretation of hydrologic studies and costs of technical methods of water retention in order to make such evaluations more realistic.

\section{AIM OF THE STUDY AND METHODS}

To estimate natural retention capacity of forests the volume of water impeded in its flow from rainfall to outflow was determined. Not particular components of 
water held in the process of interception, retention in surface waters, in litter and soil but general indicative values of water retention that reveal themselves in the forest impact on runoff were estimated. Runoff irregularity was compared with differential response of runoff to precipitation in river catchments of variable forest cover. Various terms of hampering water outflow which are important for its possible utilisation were also considered. The relationship between forest cover and the delay and equalisation of water runoff was analysed based on statistical material collected in studies performed in 40 small lowland catchments between 1966 and 2000. Mean period of precipitation and runoff surveys in particular catchments was c. 20 years. Hydrologic measurements from a 10-years-long study in the catchments of streams from the Western Sudeten were also included. The value of the runoff impeded by forest was calculated from the costs of water retention calculated for small retention objects i.e. for water stored with technical methods (WIŚNIEWSKI, 2002). They were compared with an alternative water volume retained in a natural way by forest using the factor $-1 \mathrm{~mm}$ of the layer of outflowing water equals $10 \mathrm{~m}^{3}$ of water from hectare.

\section{ESTIMATION OF THE FOREST RETENTION CAPACITY}

For proper assessment of water retention in forests it is necessary to consider the volume and time of impeded flow, the effect of forest on long-term runoff cycles, changes in the runoff terms in an annual cycle and short-term changes in the runoff intensity limiting the floods. River outflow from forest catchments depends on precipitation, on water retention and on tree stand requirements for water (TYSZKA, 2008). Long-term mean annual runoff $\left(H_{R}\right)$ in Polish Lowlands was compared with the consideration of runoff from catchments of the Great Valley Region (GVR) and its edges and the variability of percent forest cover $(\lambda)$ in particular catchments. The runoff from forested catchments situated at watersheds of larger lowland rivers (edge of the GVR) was $172 \mathrm{~mm}$ being higher by $4 \mathrm{~mm}$ than that from agricultural catchments. In alluvial river valleys (GVR) the effect of forest on runoff differentiation might be considered insignificant (mean $H_{R}=88$ ). Difference in the annual runoff equal to $2 \mathrm{~mm}$ in favour of forest catchments of Polish Lowlands was adopted as the mean in calculations.

Fundamental differences appeared in the coefficients of annual runoff irregularity $k=H_{R \max } / H_{R \text { min }}$ (Tab. 1). In selected groups of catchments the forests equalized runoff irregularity more because of increasing minimum runoffs $\left(H_{R}\right.$ min $)$ than decreasing maximum runoffs $\left(H_{R \max }\right)$.

The effect of percent forest cover $(\lambda)$ on equalizing annual runoffs (Fig. 1) may be described by the equation:

$$
H_{R \max } / H_{R \min }=6.33-0.036 \lambda
$$


Table 1. The effect of percent forest cover $\lambda(\%)$ on the coefficient of annual runoff irregularity $H_{R \max } / H_{R \text { min }}$ in small lowland catchments

\begin{tabular}{l|c|c|c}
\hline Region & $\lambda<35$ & $35<\lambda<65$ & $\lambda>65$ \\
\hline Great Valleys & 5.34 & 3.96 & 3.32 \\
Edge of the Great Valleys & 5.60 & 4.57 & 3.44 \\
\hline
\end{tabular}

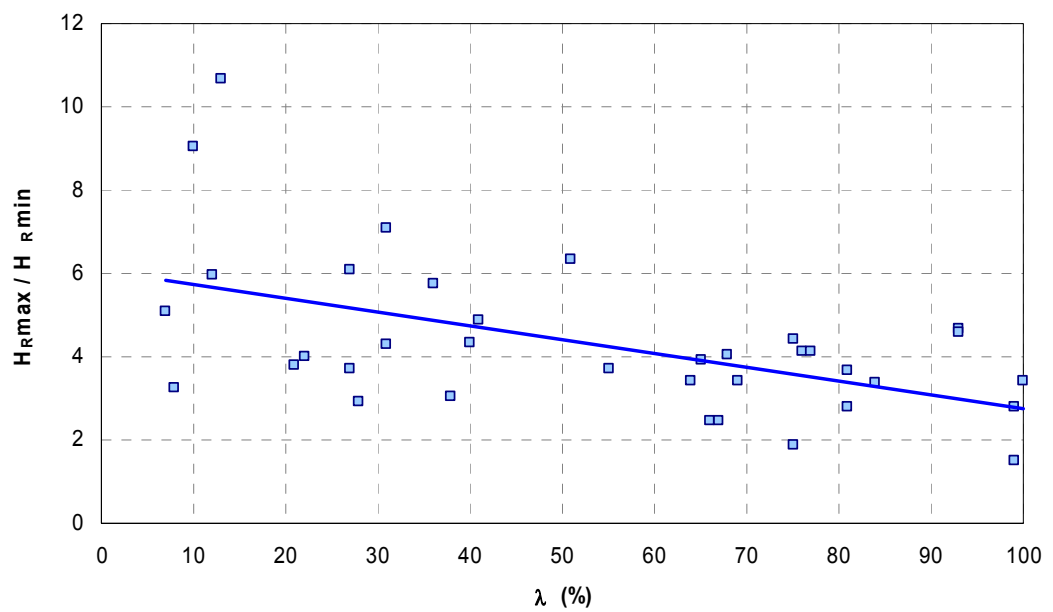

Fig. 1. The effect of percent forest cover $(\lambda)$ on the coefficient of irregularity for annual runoffs $\left(H_{R \max } / H_{R \text { min }}\right)$

where $\lambda$ - percent forest cover i.e. the ratio of forest area to the catchment basin area (in \%).

It means that the increase of forest cover from 0 to $100 \%$ results in nearly twofold decrease of annual runoff irregularity. In lowland catchments (which occupy c. $90 \%$ of the country area) of a mean runoff $H_{R}=135 \mathrm{~mm}$ it corresponds to the decrease of amplitude by $76.95 \mathrm{~mm} \cdot 100 \%^{-1}$ i.e. $0.77 \mathrm{~mm}$ per $1 \% \lambda$. It was adopted that increasing forest cover by $1 \%$ results in water retention of $0.385 \mathrm{~mm}$ in an average year.

Significant role of forests could also be seen in the relation between runoff in the winter $\left(H_{Z}\right)$ and summer $\left(H_{L}\right)$ half-year. An increase of summer runoff coincides with the period of rainfall deficit and indicates increasing usefulness of water resources in forest catchments in comparison with agricultural catchments.

Long-term mean contributions of monthly runoffs to the annual runoff are particularly high for the period from April till June i.e. in the time of intensive tree growth. Forest enrichment of the runoff in summer half-year is similar in groups of catchments of similar soil-water conditions. It is largest in catchments with deep ground water table, smaller when its displacement is shallower especially in 
catchments of mineral soils and the smallest and slower in catchments of a large $(>30 \%)$ share of hydrogenic soils (Fig. 2). Estimated ratio of summer to winter runoff for all studied catchments can be described by the equation: $H_{L} / H_{Z}=$ $0.0046 \lambda+0.56$

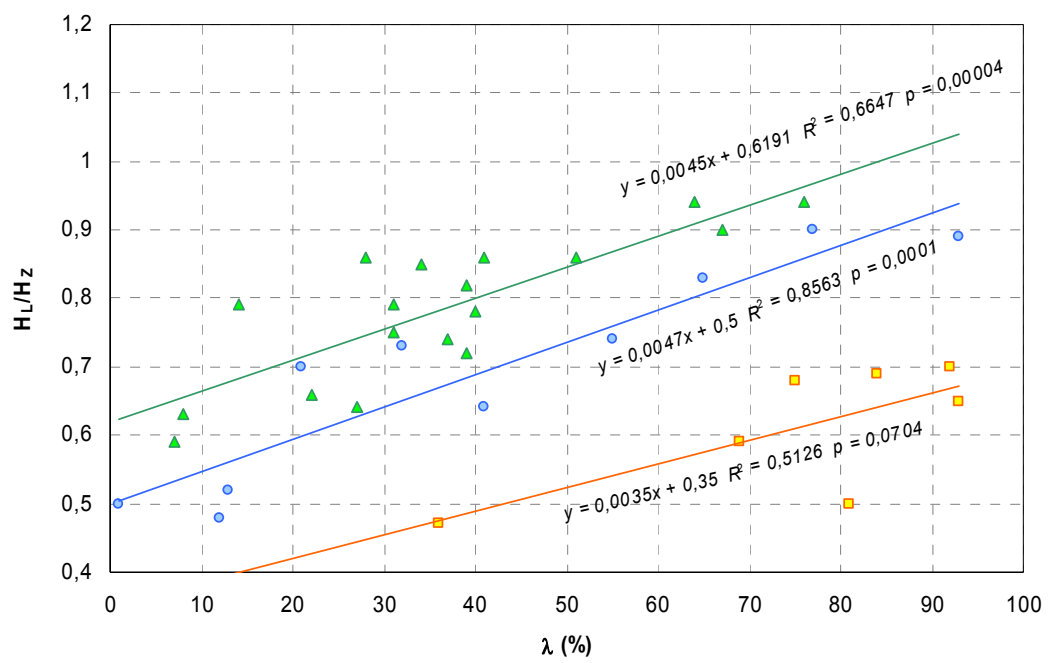

$\Delta$ mineral soils hzw $>3 \mathrm{~m} \quad \square$ hydrogenic soils $\quad \circ$ mineral soils hzw $<3 \mathrm{~m}$

Fig. 2. The effect of percent forest cover $(\lambda)$ in lowland catchments on the summer/winter runoff ratio $\left(H_{L} / H_{R}\right)$

Having in mind that mean runoff in summer half-year $H_{L}$ equals $45 \mathrm{~mm}$, its enlargement by forests may be estimated at $25.2 \mathrm{~mm}$ for $100 \% \lambda$ or $0.252 \mathrm{~mm}$ per $1 \%$ of increased forest cover.

Decreasing of maximum flows is crucial for the reduction of floods. Their relationship with forest cover was determined for 25 mountain catchments in a form of an index expressed by the coefficient of irregularity of maximum, specific $\left(1 \cdot \mathrm{s}^{-1} \cdot \mathrm{km}^{-2}\right)$ annual runoffs i.e. as the ratio of high to mean water volume $W q / S q$. The relationship was influenced by the altitude of mountain stream catchments. Below $700 \mathrm{~m}$ a.s.l. (mean altitude $644 \mathrm{~m}$ a.s.1.) the runoff of a probability of appearance near $p=5 \%$ decreased threefold with the increase of forest cover from 0 to $100 \%$ (Fig. 3) which might be expressed by the equation: $W q / S q=-0.175 \lambda+25.1$.

Similar relationship was found for lowland catchments for which, at the average water conditions in soil profile, the effect of forest cover on specific maximum runoff can be estimated from equations: 


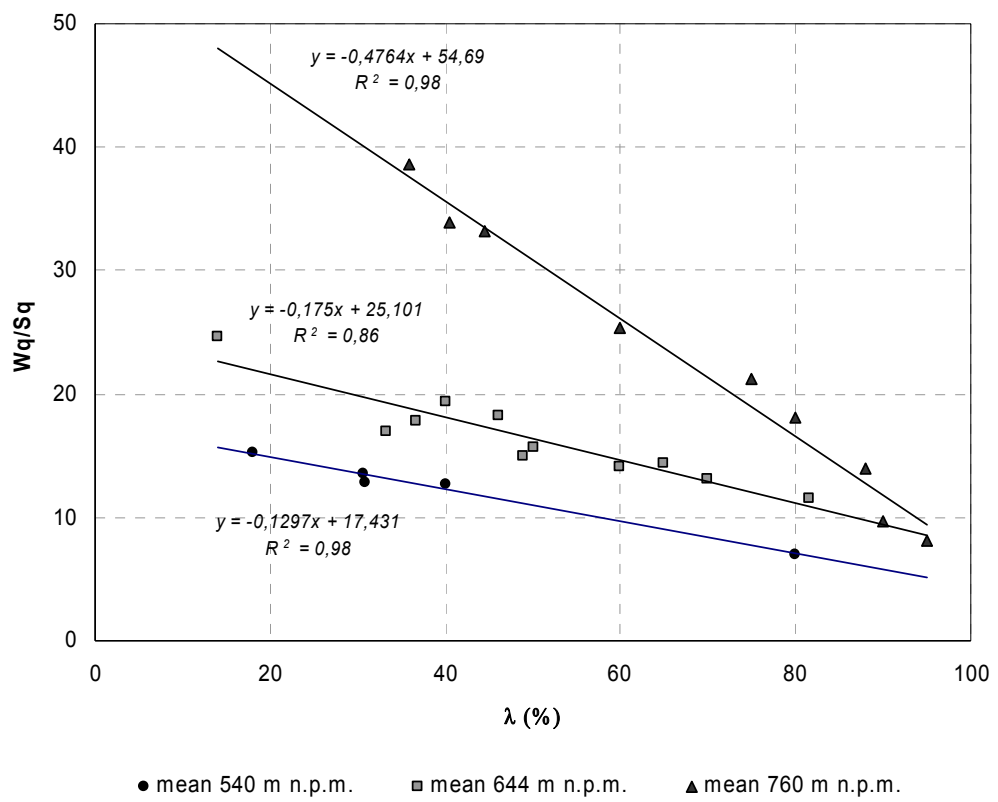

Fig. 3. The effect of percent forest cover $(\lambda)$ on the irregularity of annual maximum specific runoffs $(\mathrm{Wq} / \mathrm{Sq})$ in Sudeten brooks for different altitudes of the catchment basins

- for summer half-year $W q_{L}=-1.03 \lambda+155.4$,

- for winter half-year $W q_{Z}=-1.73 \lambda+127.9$ but only for percent forest cover between 1 and $60 \%$. With further increase in forest cover culmination flows sometimes happen to increase. It depends on forest layout and on the difference in the time of flood wave concentration in agricultural and forested areas of the catchment.

Far advanced simplification and generalisation was adopted when estimating the effect of forest on the limitation of culmination runoff: decreasing the runoff in lowlands and in the mountains by $70 \%$ on average, time of flood flow equal 2 days, single flood occurrence in a year. Mean annual flood culminations were adopted similar to those in the forested in $28 \%$ catchment of the Vistula River in Tczew with flow $S W Q=3840 \mathrm{~m}^{3} \cdot \mathrm{s}^{-1}$ (FALL, 1997) which made specific runoff of mean high water $S W q=0.01976 \mathrm{~m}^{3} \cdot \mathrm{s}^{-1} \cdot \mathrm{km}^{-2}$ or $17.07 \mathrm{~m}^{3} \cdot \mathrm{ha}^{-1}$ per day. The volume of flood runoff from forested areas decreased by $70 \%$ will give $17.07 \cdot 1.389 \cdot 0.70=$ $16.6 \mathrm{~m}^{3} \cdot \mathrm{s}^{-1}$ from hectare at the forest cover of $100 \%$ and $0.166 \mathrm{~m}^{3} \cdot \mathrm{s}^{-1}$ from hectare at $1 \%$ of forest cover i.e. $0.017 \mathrm{~mm}$ a day and 0.034 at the adopted 48 -hours long flood period.

The size, volume and shape of the flood wave is affected, apart from land use, by many climatic, morphologic, hydrologic and soil factors. To obtain relatively clear view on the forest impact on unit flood hydrograph, two most similar catch- 
ments were selected from among the studied ones which differed significantly in percent forest cover. The catchments basins of the Perebel and Chwiszcza Rivers from Białowieża Primeval Forest had the following parameters: forest cover $\lambda-$ $66 \%$ and $8 \%$, surface area $A-21.6$ and $35.5 \mathrm{~km}^{2}$, soil impermeability $W_{n}-24.5$ and 26.3 and the depth of ground water table $h_{z w}-2.0$ and $2.5 \mathrm{~m}$, respectively. Differentiated course of flood waves (Figs 4A and B) in these neighbouring catchments could be the result of unfavourable forest arrangement and small network of
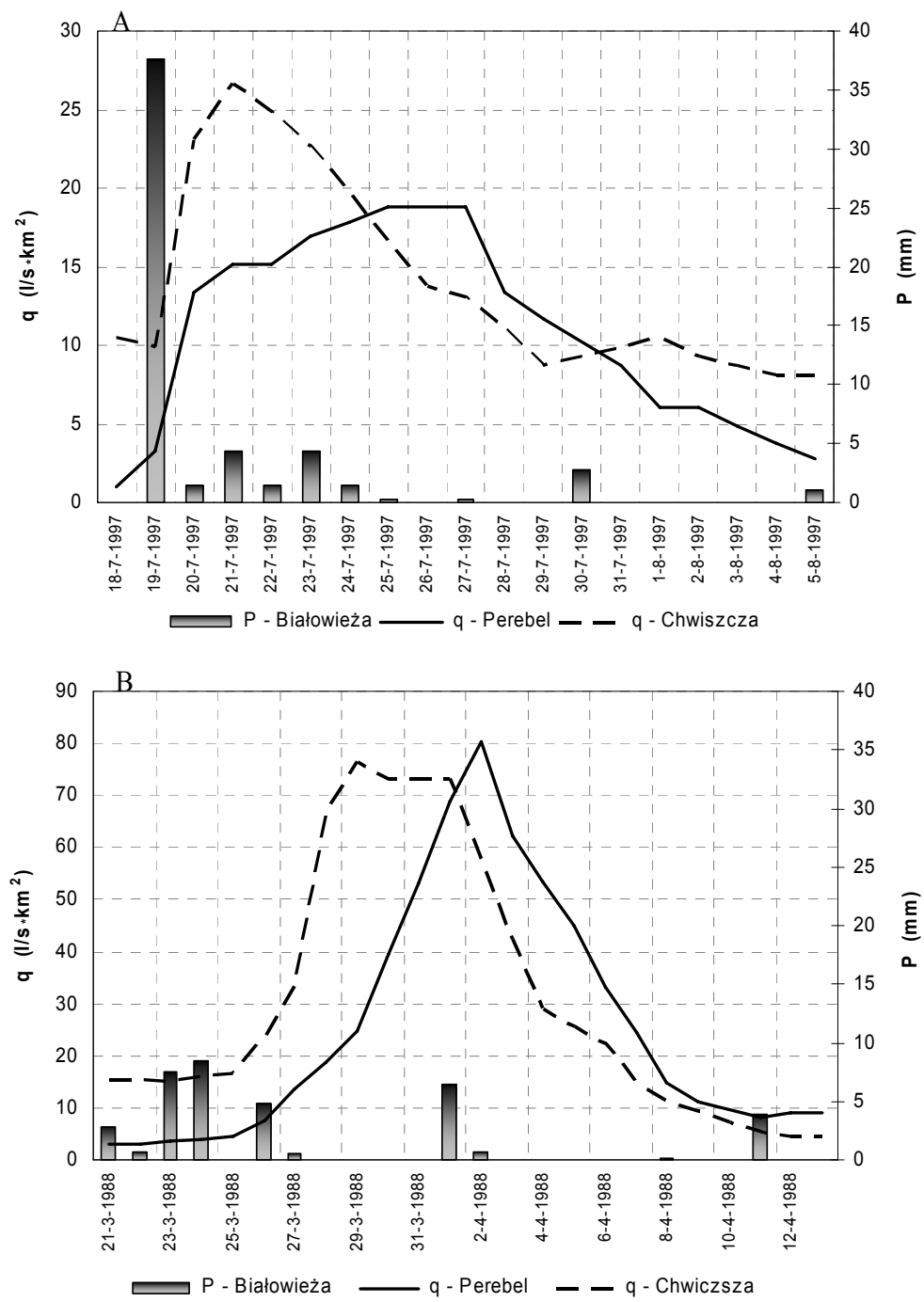

Fig. 4. Hydrographs of specific runoffs $q$ : A - rainfall flood wave, B - snow-melt flood wave in a forest catchment of the Perebel River and in an agricultural catchment of the Chwiszcza River against daily rainfall $P$ 
ditches in the forest catchment of the Perebel River. Forests of this catchment are characterised by a great share of mixed fresh coniferous forest, moist mixed forest and deciduous tree stands. Specific hydrographs of two largest floods: the rainfall one in July 1979 and snow-melt flood in March 1980 indicate significant differentiation in the terms of culmination, volume of flood wave and in the case of summer wave - also in maximum outflow. This confirms the objectivity of performed analyses and the leading role of forest in limiting flood runoff (especially visible in coniferous forest habitats) and consequently - in decreasing flood risk.

Water retention in forests was assessed by summing up its various elements (Tab. 2).

Table 2. Mean annual values of water retention in forest

\begin{tabular}{lcc}
\hline \multicolumn{1}{c|}{ Type of retention function of forests } & $\mathrm{mm} \cdot 100 \% \lambda^{-1}$ & $\mathrm{~m}^{3} \cdot \mathrm{ha} \cdot 1 \% \lambda^{-1}$ \\
\hline Mean annual runoff $H_{R}$ & 2.0 & 0.20 \\
Equalization of annual runoffs $H_{R \text { max }} / H_{R \text { min }}\left(\right.$ mean $\left.H_{R}=135 \mathrm{~mm}\right)$ & 38.5 & 3.85 \\
Increasing of summer runoff $H_{L} / H_{R}\left(\right.$ mean $\left.H_{L}=45.0 \mathrm{~mm}\right)$ & 25.2 & 2.52 \\
Decreasing of flood waves $S W q(p=5 \%)$ & 3.4 & 0.34 \\
Total & 69.1 & 6.91 \\
\hline
\end{tabular}

Total amount of natural water retention in forests may be thus estimated as equivalent to a water reservoir of a volume of $6.91 \mathrm{~m}^{3} \cdot 28 \%=193.5 \mathrm{~m}^{3}$ per average hectare of the country area.

\section{VALUATION OF THE NATURAL FOREST RETENTION CAPACITIES}

Evaluation was carried out on the assumption that:

- relationships for forest hydrology elaborated for small studied catchments apply for the whole area of Poland,

- environmental factors other than those associated with forests do not affect the variability of water retention,

- the effect of forest on flow culmination is reflected in the volume of flood wave which was assumed to be equivalent to the volume of 48 -hours flow.

Costs of water storage in the small retention objects in forests are quite variable and depend on the size of reservoir (increase with declining volume) and on technical investments (increase due to earth works, construction of weirs etc.). Examples of the costs of water storage in objects built in State Forests until 2001 are shown in Table 3.

The costs of investments associated with water storage varied from $2.5 \mathrm{zl}$ to $200 \mathrm{zl}$ per $1 \mathrm{~m}^{3}$. The lowest costs achieved in the Forestry Commission Garwolin were taken for further calculations. They were estimated as a cost of construction 
Tabla 3. Costs of water retention in small retention reservoirs built in State Forests before 2001

\begin{tabular}{|c|c|c|c|c|c|}
\hline Number & Calculation & $\begin{array}{c}\text { Area } \\
\text { ha }\end{array}$ & $\begin{array}{c}\text { Volume } \\
\mathrm{m}^{3}\end{array}$ & $\begin{array}{c}\text { Depth } \\
\text { m }\end{array}$ & $\begin{array}{c}\text { Cost } \\
\text { of retention }\end{array}$ \\
\hline \multicolumn{6}{|c|}{ State Forests } \\
\hline \multirow[t]{2}{*}{743} & total & 930 & 5404757 & - & $31502000 \mathrm{zl}$ \\
\hline & unit & 1.25 & 7.274 & 0.58 & $5.83 \mathrm{z} \cdot \mathrm{m}^{-3}$ \\
\hline \multicolumn{6}{|c|}{ Forestry Commission Garwolin } \\
\hline 36 & unit & 0.38 & 6.038 & 1.59 & $4.00 \mathrm{zł} \cdot \mathrm{m}^{-3}$ \\
\hline \multicolumn{6}{|c|}{ Notecka Forest } \\
\hline 41 & unit & 2.03 & 22.264 & 1.10 & $10.90 \mathrm{zł} \cdot \mathrm{m}^{-3}$ \\
\hline \multicolumn{6}{|c|}{ The Sudeten } \\
\hline 14 & unit & 0.27 & 3290 & 1.21 & $64.40 \mathrm{zl} \cdot \mathrm{m}^{-3}$ \\
\hline
\end{tabular}

of a small water reservoir enlarged by annual operating costs i.e. at $4.15 \mathrm{z} \cdot \mathrm{m}^{-3}$. Considering fairly simplified calculations the value of annual retention functions of forests might be approximately estimated at $193.5 \mathrm{~m}^{3} \cdot 4.15 \mathrm{zł} \cdot \mathrm{m}^{-3}=803 \mathrm{zl}$ per hectare of the country area.

\section{EFFECTS OF WATER RETENTION WITH TECHNICAL METHODS AS COMPARED WITH NATURAL RETENTION CAPACITIES OF FORESTS}

Forms and range of water retention achieved by technical stream built-up do not objectively reflect the importance of small water retention for forest and external users. Treating small water reservoirs as a form of counteracting the impoverishment of water resources in forests is somehow insufficient. The main deficiency of such treatment lies in the limited impact of water reservoirs on surrounding forest habitats. Under favourable hydrogeologic conditions the effect of a reservoir on groundwater table and moisture of soil profile ranges several hundred metres. Under average conditions of Polish Lowlands the range is several dozen metres and in mountains it may sometimes be limited to a shore belt several metres wide. It does not negate the importance of reservoirs for species diversity but does not compensate large-scale drying of forest habitats. In habitats most affected by drying there is no possibility of increasing water retention in reservoirs due to a lack of running or ground water resources.

There is no better way of increasing hydrotechnically the habitat moisture than through the systems of ditches. At a small volume of stored water, thanks to long shoreline, the ditches are able to change water relations in large areas. The efficiency of water retention (measured as the ratio of surface to ground water volume) is many times higher in ditches than in water reservoirs. Irrigating effect of ditches is similar to the impact of very small water pools. Therefore, it is postulated to increase the number of micro-retention objects to improve water relations in forests 
(PIERZGALSKI et al., 2005). In that way one may obtain water useful for forests and affect its natural cycling.

The main problem from the point of view of external users is to increase useful river outflow through affecting the amount of water and its temporal distribution, to improve water quality and to recharge groundwater resources. Fulfilling water demands of trees often stands in contradiction with the use of water for consumption and economic purposes. Cheaper facilities that don't need service, equipped with a fixed level of water raising are preferred in forests while external users require steered appliances to dam surface waters. It is necessary to bear additional costs associated with modernization of technical facilities of small retention and labour-consuming exploitation and conservation in order to perform rational water management that enable reaction to annual and long-term changes in water resources.

When adopting technical solutions one has to keep in mind that for hydrobiological reasons it is necessary to maintain minimum acceptable flows and that limitation of maximum flows needs appropriate volume of the retention reservoir or coordinated operation of a cascade of small reservoirs. The effect of reservoir on river flow was simulated with the SYSMOR model (SZYMCZAK and KOWALEWSKI, 1999) with the consideration of the shape of flood wave typical for the Western Sudeten (TYSZKA, 2001). Assuming the flow of $5.0 \mathrm{~m}^{3} \cdot \mathrm{s}^{-1}$ with the probability of occurrence of $1 \%$, the efficient (above 6.5\%) decrease of maximum flows could be obtained with the reservoir capacity larger than $15 \%$ of wave volume at the inflow (Fig. 5). The effect obtained that way is equivalent to the increase of percent forest cover by $0.8 \%$.

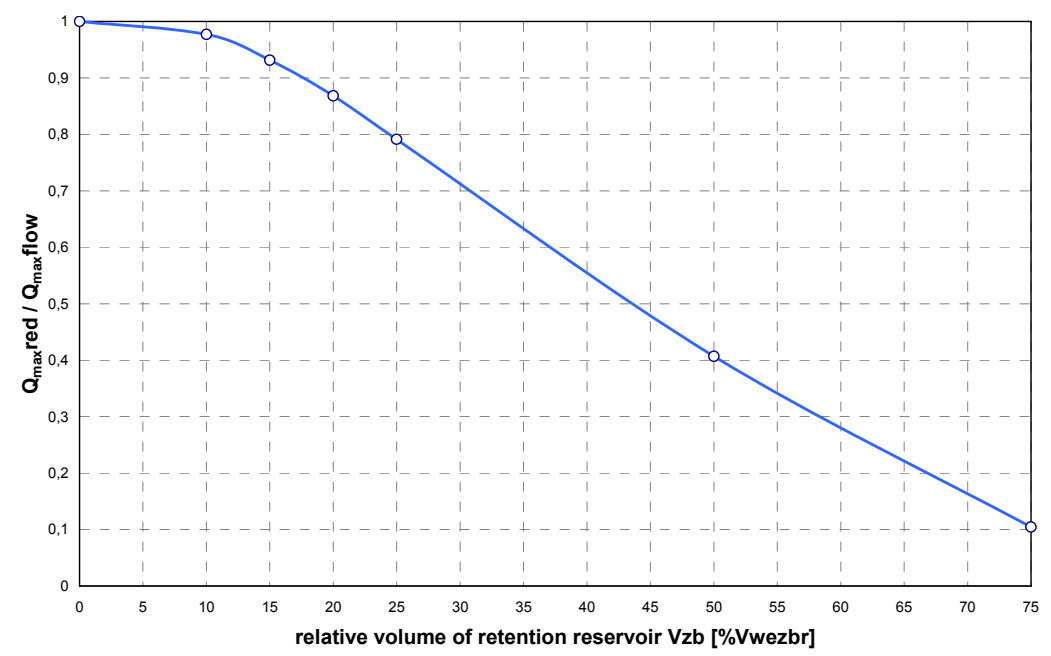

Fig. 5. The relationship between reduction of the culmination wave and relative volume of retention reservoir $\left(V_{z b}\right)$ 


\section{CONCLUSIONS}

1. Forest in a natural way inhibits river outflow and:

- decreases culmination flows and the volume of flood wave,

- increases outflow in the months of water deficit (April-June),

- limits the coefficient of annual runoff irregularity.

Forests increase atmospheric precipitation and at the same time create conditions for more effective use of water resources. Water retention in forest is of a large-scale character.

2. Annual value of the retention capacity in Polish forests may be estimated at 800 zl per mean hectare of the country area. Apart from stabilizing climate, increasing species diversity, "filtering" air, water and soil, and providing recreational values forests play biologically important and economically valuable role in adopting water cycles to its use for natural and economic purposes.

3. Technical measures of improving surface water retention in forests should supplement their natural retention capacity in order to increase water resources in forest habitats and to improve water alimentation in river catchments. Efficient water retention activities require competent water management to combine water demands of tree stands with the needs of external users.

4. Services responsible for water management in the country should cooperate with forest administration and undertake decisions that would meet the expectations of various water users interested in the improvement of water supply under changing climatic conditions. Cost analysis considering natural and technical alternative determinants of water retention is necessary to decide upon methods of improving water cycling.

\section{REFERENCES}

1. FALl B., 1997. Przepływy charakterystyczne głównych rzek polskich w latach 1951-1990. (Characteristic flows of the main Polish rivers in the years 1951-1990). Mater. Bad. IMGW, 21: 143.

2. SZYMCZAK T., KowALEWSKi Z., 1999. An impact of small water reservoirs on reduction of storm flow hydrographs and increase of base flow. Intern. Symp. New Approaches Irrig. Drain. Flood Control Manag. Bratislava, Slovak Republic, 12-14 May 1999.

3. TYSZKA J., 2001. Zasady gospodarowania zasobami wodnymi w lasach ze szczególnym uwzględnieniem małej retencji w regionach górskich. (Principles of water management in forests with special reference to small retention in mountain areas). Dokumentacja. Sękocin Stary, IBL.

4. TYSZKA J., 2008. Hydrologiczne funkcje lasu w małych nizinnych zlewniach rzecznych. (Hydrologic forest functions in small lowland river catchments). Pr. IBL Rozpr. Monogr., 10: 215.

5. PierzGalski E., CiePielowski A., TyszKa J., WiŚniewski S., 2005. The rules of water management in forests. In: Protection of soil and water resources in forestry areas. Ed. E. Pierzgalski, S. Niemtur, J. Czerepko. Sękocin, IBL: 163-181.

6. WIŚNIEWSKI S., 2002. Realizacja małej retencji w latach 1998-2001 w Lasach Państwowych. (Accomplishment of small water retention in State Forests in the years 1998-2001). Mater. DGLP, Warszawa. 


\section{STRESZCZENIE}

\section{Ocena oraz wycena wartości ekonomicznej retencyjnych właściwości lasu}

Słowa kluczowe: las, retencja wodna, wycena ekonomiczna

Wobec potrzeby racjonalizowania gospodarowania zasobami leśnymi podjęto próbę oceny i wyceny naturalnych retencyjnych właściwości terenów leśnych. Ocenę wpływu lasu na wielkość i czas spowolnienia odpływu wody przeprowadzono na podstawie wyników długoletnich badań w małych zlewniach rzecznych. W procesie retencjonowania wody wyróżniono wpływ lasu na zwiększenie ogólnej ilości odpływu i udziału odpływu półrocza letniego w odpływie rocznym oraz zmniejszenie nierównomierności odpływów rocznych i wielkości wezbrań kulminacyjnych. Obszary leśne magazynują w średnim roku niemal $70 \mathrm{~mm}$ wody w różnych formach. Ogólna, sumaryczna wielkość retencji związanej z lasem, wyznaczona w skali roku dla statystycznego hektara powierzchni Polski (28\% lesistości), wyniosła $193,5 \mathrm{~m}^{3}$. W dalszej kolejności określono koszty związane $\mathrm{z}$ magazynowaniem wody w małych zbiornikach retencyjnych wybudowanych w ostatnich latach na terenie leśnym, przyjmując $4,15 \mathrm{zł} \cdot \mathrm{m}^{-3}$. Wycenę ekonomiczną wody retencjonowanej przez las obliczono jako iloczyn jej objętości i ceny. Wartość ekonomiczną naturalnych właściwości retencyjnych lasu dla statystycznego hektara powierzchni Polski można oszacować na $800 \mathrm{zł} \cdot \mathrm{rok}^{-1}$ oraz na $2668 \mathrm{zł}$ w ciągu roku $\mathrm{z} 1$ ha lasu. Ze względu m.in. na różne znaczenie naturalnej retencji wodnej lasu i efektów retencyjnych, osiaganych w wyniku inwestycji technicznych, należy tę kwotę traktować jako orientacyjną.

Reviewers:

Dr. Piotr Gołos

Dr. Tomasz Szymczak 